\title{
Field application of tick-decoy coated with pheromone technology as a mean of Boophilus annulatus tick control
}

\author{
By \\ Aggour, M.G*. and Mohran, K.A*. \\ * Biotechnology Department -Animal Health Research Institute, Dokki, \\ Giza.
}

\begin{abstract}
$\underline{\text { Abstract }}$
Eradication of the cattle tick "Boophilus annulatus" was achieved by using the tick decoy technology. The identification and analysis of the female tick pheromone composition were carried out using thin layer chromatograph (TLC) and high pressure liquid chromatography (HPLC). Bioassays were done to determine the B.annulatus male responses to the prepared B.annulatus female pheromone. The results showed high male responses (56.66\%). Application of manufactured pheromone - pyrethroid decoys of the male B.annulatus ticks gave great mortality of ticks ( $83.33 \%$ ) . A field trial to evaluate the efficiency of tick decoys coated with Boophilus annulatus pheromones was done on eight cows.Decoys containing 10\% ectomin were used. Each cow was naturally infested with 25 female and 25 male Boophilus annulatus ticks. Fifty pheromone ectomin impregnated decoys were glued in the predilection seats to each cow of the experimental group. Following decoys attachment, male ticks began to detach, attracted to the decoys and died with mortality rate reached $76 \%$. Female ticks after incubation laid unfertile eggs.

Key words $=$ Boophilus annulatus, pheromone , Decoys , Thin layer chromatography (TLC) and High pressure liquid chromatography (HPLC) .
\end{abstract}




\section{Introduction}

Control of ticks in Egypt, usually depends upon traditional methods e.g. Dipping, spraying and pour on using different acaricides e.g. chlorinated hydrocarbons, organophosphates and naturally as well as synthetic pyrethrins ( Ristic, 1988) .

Biological control is now tried as a safe, economic and effective method for tick eradication. Methods of biotechnology and recent advances in instrumentation have enabled scientists to begin to appreciate the incredible diversity of compounds incriminated in chemical communication used by animals to transmit information between individuals.

Pheromones are chemicals emitted by living organisms to send messages to individuals of the same species (Karlson and Luscher, 1959). The use of pheromones offers an exciting, innovative approach to future development of tick control techniques. Pheromones are likely to be most effective when used in combination with toxicants. Pheromones may be used as lures (Gladney et al., 1974), sexual confusants (Ziv et.al, 1981), assembly agents or even as repellents (Sonenshine, 1985).

Mating behavior in ticks is regulated by sex pheromones produced by female ticks which are used to attract conspecific males. Tick control can be achieved with pheromone traps with a technique called " tick decoy ", in which synthetic pheromone impregnated decoys lead to mating disruption and the number of mating and off springs is reduced. Fifty percent of Amblyomma variegaturn female population were able to find upwindpositioned targets containing the synthetic aggregation - attachment pheromone of this species or the pheromone component $\mathrm{O}$ - nitrophenol alone (Hess and De-Castro, 1986)

Three low molecular weight compounds were found in hexane : diethyl ether extracts of fed males of the African ticks, Amblyomma variegatum (tropical bont tick) and A.hebraeum (bont tick), namely, onitrophenol, methyl salicylate and 2,6-dichiorophenol (Lusby et al, 1991).

Unfed adults and nymphs of the bont tick Amblyomma hebraeurn were attracted to hosts on which fed males emitting an aggregationattachment pheromone (AAP), were present. Pheromone /acaricide mixtures (decoys) have the potential to selectively attract and kill these ticks. The effects of three acaricides, amitraz (an amidine), flumethrin (a synthetic pyrethroid) and chlorfenvinphos (an organophosphate), combined with AAP, on the attraction and attachment of the unfed adults were investigated. Flumethrin caused rapid and high mortality in attached and unattached ticks and was superior to the other two acaricides (Norval et al, 1991 a,b).

Unfed adults of the African ticks, Amblyomma hebraeuni and A. variegaturn, were exposed to volatile compounds in an olfactormeter in 
efforts to identify both tick-produced or synthetic chemicals capable of eliciting an attraction response. They concluded that ticks respond positively to a variety of volatile chemicals (synthetic pheromone), which may conceivably be used to attract them to traps, animals or acaricides in efforts to control ticks or the diseases they transmit (Yunker et al, 1992).

The presence of a mounting sex pheromone on the surface of fed female dog tick (Rhipicephalus appeniculatus) was demonstrated. This pheromone, which is present on the female cuticle, allows the male to recognize the female. The pheromone was removed by cleaning the female in hexane, resulting in the loss of male mating behavior in vitro experiments. Male mating behavior was resumed when extract made from fed female cuticle was replaced on cleaned females. When the extract was transferred to inanimate objects typical male mating behavior was released. Preliminary chemical analyses indicated that the active component of the extract was contained in the sterol ester fraction of the extract (Hamilton et al, 1994).

Studying the pheromone composition using TLC and HPLC explained that cholesteryl esters were found to constitute a major component of the lipids coating the body cuticle of females of the camel tick, Hyalomma dromedarii and the brown dog tick, Rhipicephalus sanguineus. One or more cholesteryl esters, alone or in combination, have been shown to serve as the mounting sex pheromone of several species of ixodid ticks (Sobbhy et al, 1994).

The use of decoys coated with $H$. dromedarii female pheromones and impregnated with cyfluthrin experimentally on infested rabbits showed the attraction of fed males toward decoys and $72.77 \%$ mortality among ticks were recorded . Also the eggs from the survived females reached only $20-$ 23 hatching (Fahmy and Aggour, 1995).

A test to evaluate the efficacy of tick decoys impregnated with Hyalormma dromedarii pheromones on nine camels was performed as a first trial in Egypt. They used tick decoys containing $10 \%$ cyfluthrin of decoy weight. Each camel was naturally infested with about 25 female ticks and 25 male ticks. Six of animals were served as the experimental group while other three were served as the control group. About 50 pheromone / cyfluthrin impregnated decoys were glued to each camel in the experimental groups (total 300 decoys). Following decoys attachment, male ticks began to detach and were attracted to the decoys, many died and dropped off. Female ticks after incubation either died without oviposition or laid infertile eggs, presumably because they were never inseminated (Aggour and Abd ElGawad, 1995). 


\section{MATERIALS AND METHODS}

\section{Materials}

1. Ticks (for pheromone preparation): About 2000 ticks were collected from naturally infested cows from different investigated farms, and identified according to Hoogstraal (1956).

2. Tick extract solvent: Hexane: diethyl ether (90: 10) GC-grade.

3. Standards GC-grade (from sigma): Cholesteryl esters , Cholesterol , 2,6Dichiorophenol (DCP), Triglycerides and Fatty acids. Each standard was put in a labeled vial, sealed and kept in freezer.

4. SOLVENTS for THIN LAYER CHROMATOGRAPHY (TLC): petroleum ether, diethyl ether and acetic acid.

5. PLATES: High-performance precoated silica gel, glass backing plates were used. HPTLC type (LHP-K).

6. Drummond micropipette: for application of samples on the plates.

7. High Pressure Liquid Chromatography (HPLC) : Waters HPLC system comprising a model 721 system controller for the UV detector), Paired model 510 pumps, Model U6K injector, Model 996 photodiode array detector (PA), Whatman ODS-3 reversed phase analytical column $25 \mathrm{~cm} \mathrm{x}$ $6.35 \mathrm{~m} . \mathrm{m}$ and control of all PA and pump operations was done with the Waters Millennium system.

\section{Methods:}

1. Comparison between standards (cholesteryl esters, cholesterol, triglycerides and fatty acids) and tick extract using thin layer chromatography (high performance thin layer chromatography plates) according to Fried and Sharma (1982)

\section{Purpose:}

to determine the lipids present in tick extract, especially cholesteryl esters, cholesterol, free fatty acids and triglycerides.

\section{Procedures:}

1.1. Preparation of tick extract: 1000 engorged female Boophilus ticks were placed in a mixture of pure GC- grade Hexane : diethyl ether $(90: 10)$ in a glass container with a ground glass stopper and put on shaker for 2-3 minutes. This mixture was concentrated to about 1-2 $\mathrm{ml}$ under a gentle stream of nitrogen gas, then transferred to a glass ampoule with a conical bottom and sealed carefully (using Teflon and paraflim paper), after that stored in freezer until ready for use (at $\left.-20^{\circ} \mathrm{C}\right)$.

1.2. Preparation of standards: $1 \mathrm{mg} / \mathrm{ml}(1 \mu \mathrm{g} / 1 \mu \mathrm{L})$ hexane using a chromatographic microbalance (sensitivity $0.1 \mu \mathrm{g}$ ). $\mathrm{gc} / \mathrm{ms}$ grade. The 
standards (Cholestryl esters, cholesterol, 2,6, DCP, Triglycerides and Fatty acids) obtained from Commercial Supplier (Sigma) were weighed out and adjusted to a concentration of $1 \mathrm{mg} / \mathrm{ml}$. $2 \mathrm{ml}$ total for each standard was put in a labeled vial, sealed and kept in freezer.

1.3. Preparation of solvents The solvent system was prepared as follows: total $300 \mathrm{ml}$ for each.according to System I (Mangold, 1969) : Petroleum ether :diethyl ether :acetic acid (80:20:1) or System II (Skipsi et at, 1965):

a) Petroleum ether : acetic acid ( $96: 4)$

b) Petroleum ether: diethyl ether : acetic acid ( $90: 10: 1$ )

The solvent was placed in a rectangular glass tank with lid. The tank was lined on three sides with thick filter paper that is thoroughly soaked with the solvent. The tank allowed to stand for $30 \mathrm{~min}$. to one hour to allow the inside atmosphere to be saturated with solvent vapor.

1.4-Plates: High-performance (HP) precoated silica gel, glass backing plates were used. Clean HPTLC plates by placing them in the tank containing any solvent prepared and then dry (oven or air dry), then divided into 5-6 lanes.

1.5- Application of samples : $5 \mu 1$ of each sample was applied by using Drummond micropipet. Dry samples thoroughly before development (hair drier is used). Plates were placed in the tank containing the solvent.After development, the plate was removed and oven dried at $100{ }^{\circ} \mathrm{C}$ for $3 \mathrm{~mm}$. Next the plate is sprayed with $50 \% \mathrm{H}_{2} \mathrm{SO}_{4}$ and $50 \%$ Methanol and dried in an oven $\left(90-100{ }^{\circ} \mathrm{C}\right)$ and cooled to room temperature. The spots visualized in this manner are examined and the spots in the sample lane are compared with the spots in the different lanes for the standards. Spots that have the same $\mathrm{R} f$ value ( $\pm 5 \%$ )are considered to be the same class of compound. Tick extract spots are compared with those of the standard, to determine their identification to class.

\section{Analysis using high pressure liquid chromatography. (HPLC) Purpose:}

- Measuring the retention time and maximum wave length of peak of tick extract.

- Comparison between curves of standards and curves of tick extract, using the Waters photodiode Array Detector and Millennium Software System. 


\section{Procedures:}

2.1. Preparation of solvents :The solvents (Isopropyl alcohol \& Acetonitrile) were filtered and degassed for at least 20 minutes. The flow rate was 120:80 respectively.

\subsection{Analysis of data was done using millennium.}

3 . Manufacturing and testing of tick decoys : According to (Aggour and Abdel-Gawad 1995)

Procedures for manufacture of tick decoys: 220 grams of PVC resin (Goodrich Geon 138) were mixed with 220 cc dioctylphthalate. Then $20 \mathrm{ml}$ Drapex 6.8 stabilizer was added together with $6 \mathrm{ml}$ of Mark Red antioxidant. All ingredients were mixed thoroughly with the electric mixer until the mixture was unifonnly mixed and could be poured. The mixture was allowed to stand overnight. Sufficient 2,6-dichiorophenol was added to equal $0.1 \%$ of the final product (approximately $220 \mathrm{mg}$ ). Sufficient acaricide (Ectomin) was added to equal $10 \%$ of the 220 grn. The mixture was poured into molds and placed in the oven at $145{ }^{\circ} \mathrm{C}$ for 20 minutes. a mixture of standards proved to be found in the tick extract in hexane was prepared to be deposited on the plastic decoys. The mixture contained also butylated hydroxytoluene $1 \%$ by weight of the final mixture.

4. Bioassay: Two types of bioassay were carried out according to (Hamilton and Sonenshine, 1988) on conspecific and on, inanimate objects (decoy). All male ticks were prescreened to ensure that only that were responding to females were used in bioassays. Females were also prescreened to ensure that they we-re capable of exciting a mating response by the male before being cleaned. The females were cleaned and delipidized using Hexane to ensure that they would no longer attract males before the extract was applied. Bioassays were performed in the laboratory at approximately $25{ }^{\circ} \mathrm{C}$ on filter paper in a 9-em-diam. Petri dish. The response of the male when presented to the imobilized female was scored by a system based on the mating behavior sequence described by Sonenshine (1985). The female was immobilized by attaching its anterior end to adhesive tape. The mating behavior sequence used in these experiments was as follows: Orientation of the male towards the female or "dummy" female (decoy), awareness of the female (touching with appendages, mounting of the female, turning on the dorsal surface of the female and movement of the male to the ventral surface of females. Each stage was given one point when the male had achieved that stage. The number of points gained by each male was recorded. The first two stages were not included in the final analysis as they are a measure of the 
attractiveness of the 2,6-DCP. Thus a completely successful male would gain three points. The number of points gained by the males in their response to female extracts was totaled and compared to the control for comparing percentages.

\section{5- Field application of tick decoy technology :}

Animals : Eight cows naturally infested with Boophilus annulatus ticks ; five of them were used as experimental group (ticks and decoys) while the other three ones served as control group (ticks only).

Ticks: Each cow was naturally infested with 25 semi-engorged female and 25 active male Boophilus annulatus ticks

Sex Pheromones : Boophilus annulatus sex pheromones were synthetically prepared from authentic standards (Sigma) .

Decoys : The plastic decoys used were prepared at Biotechnology Dept., Animal Health Research Institute Giza, Egypt; according to (Aggour and Abd EL-Gawad,1995). Mixture of the pheromone constitutes in hexane was deposited on the plastic decoys shortly before application .

Experiment : The experiment was done according (Aggour and Abd ELGawad,1995) as follow: Fifty pheromone/ectomin-impregnated decoys were attached to each cow in the experiment group by using Pattex contact cement along the back, neck, back of head, near anus, near udder and elsewhere (photo 1).

The eight cows were isolated in a clean stall to avoid additional tick infestation; the floor was provided with double sided barrier to capture the fallen ticks for ease and accurate observation.

Observations on the behavior of the ticks were recorded within shortly after applications on the decoys and then daily for 10 days as follows:

- Number of males attempt to mount decoys.

- Number of males dropped dead on the floor.

- Number of males dropped live on the floor.

- Number of males attached dead on animals.

- Number of males attached live on animals.

- Number of mated engorged females attached to each animal.

- Number of decoys still attached on animal.

- Number of decoys dropped on ground.

The living ticks (male and females) were incubated in a biological incubator at $28^{\circ} \mathrm{C}$ and $75 \%$ R.H. and the engorged females were observed for oviposition and egg hatching. 


\section{RESULTS}

\section{Qualitative comparison between standards and pheromonal tick extract using (TLC)}

Analysis of pheromonal tick extract was done in comparison with standards using High-Performance (HP) precoated silica gel, glass backing plates. The solvents used were petroleum ether, diethyle ether and acetic acid.

The results showed that the tick extract contains the following cholestryl esters: cholesterol, ch. linoleate, ch laurate, ch. linolenate, ch. oleate, ch . myristate, ch. butyrate, ch. stearate, ch. palmitate. In regard to Triglycerides, the tick extract matched with Tnuinolein, Trilinolenin, Trilaurin, Tri-ecosenoin, Tripalmitin, Tripalmitolin and Tricaprylin. Concerning the fatty acids, only three fatty acids developed and matched with the tick pheromone. Those were Linoleic acid, Linolenic acid and Arachidonic acid.

2. Quantitative comparison between standards and B.annulatus extract (pheromone using HPLC: Quantitative analysis of the B. annulatus pheromone and its comparison with the different standards (Cholesteryle esters, Triglycerides and Fatty acids) were done using Waters Millennium system, using isopropyl alcohol and acetonitrile solvent at flow rate 120:80 respectively. The matching was based upon measuring the retention time and maximum wave length of peak of tick extract and those of the standards. The results obtained were displayed in table (1).

Table (1) : The component of the B.annulatus pheromone from the authetic standards using HPLC analysis

\begin{tabular}{|l|c|l|c|l|c|}
\hline $\begin{array}{c}\text { Cholesteryl } \\
\text { Esters }\end{array}$ & $\begin{array}{c}\text { Conce. } \\
\mu \mathrm{g} / \text { tick }\end{array}$ & \multicolumn{1}{|c|}{ Triglyceride } & $\begin{array}{c}\text { Conce. } \\
\mu \mathrm{g} / \text { tick }\end{array}$ & \multicolumn{1}{|c|}{$\begin{array}{c}\text { Fatty } \\
\text { acids }\end{array}$} & $\begin{array}{c}\text { Conce. } \\
\mu \mathrm{g} / \text { tick }\end{array}$ \\
\hline Ch Oleate & 4.6 & T. Laurin & 121.4 & Stearic & 8.4 \\
\hline Cb Hexanoate & $\mathbf{1 0 . 1}$ & T. Caprin & $\mathbf{2 0 . 3}$ & Oleic & 5.8 \\
\hline Ch Lrnolenate & $\mathbf{8 . 1}$ & T. Elaidin & 17.4 & Palmitic & 4.3 \\
\hline Ch Butyrate & 9.2 & T.Palmitin & 20.6 & Arachidonic & 1.7 \\
\hline Ch Palmitate & 5.6 & T. Stearin & $\mathbf{2 2 . 1}$ & Arachidic & 4.9 \\
\hline Ch Hnoeate & 3.8 & T. Caproin & 15.9 & Linoleic & 22.5 \\
\hline Ch.Myristate & 4.9 & T.Linolein & 67.8 & Linolenic & 12.8 \\
\hline Ch.Stearate & 4.7 & T.Caprylin & 60.2 & Lauric & 14.1 \\
\hline Ch Laurate & 1.2 & T. Palmitolein & 143.6 & & \\
\hline Cholesterol & 12.2 & T. Ecosenoin & 117.4 & & \\
\hline 2,6-DCP & 1.0 & & & & \\
\hline
\end{tabular}




\section{Bioassay}

The results of tests of $B$. annulatus male responses to the synthetic mixture representing the B.annulatus pheromone were summarized in table (2).Untreated and delipidized (body surface washed with hexane to remove lipids) females as well as manufactured decoys were used in the test.Bioassays were done with sexually active $B$. annulatus males and

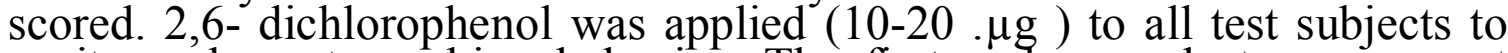
excite male mate seeking behavior. The first and second stages are not included in calculation. Responses in excess of $20 \%$ were considered positive.

Table (2) : Results of bioassay of B.annulatus

\begin{tabular}{|l|l|l|}
\hline Compound tested & $\begin{array}{l}\text { No. of positive male } \\
\text { responses }\end{array}$ & $\%$ positive \\
\hline Living untreated control females & $19 / 30$ & $63.33 \%$ \\
\hline Synthetic mixture on delipidized females & $17 / 30$ & $5666 \%$ \\
\hline Synthetic mixture on manufactured decoys & $16 / 30$ & $53.33 \%$ \\
\hline Delipidized female with hexane only & $\mathbf{2} / 30$ & $6.66 \%$ \\
\hline
\end{tabular}

Pheromones- acaricide mixture was added to dummy ticks (decoys) as a means of tick eradication using biotechnology. Pyrethroid (Ectomin) treated pheromonal coated $(10 \% \mathrm{w} / \mathrm{v})$ and non- pheromonal decoys were applied on male B.annulatus tiks and the results are shown in table (3).

Table (3) : Effect of Pheromone-Acaricide Decoys on Male B.annulatus Ticks

\begin{tabular}{|l|c|c|c|c|}
\hline Compound tested & $\begin{array}{c}\text { No.of positive male } \\
\text { responses }\end{array}$ & $\begin{array}{c}\% \text { of } \\
\text { responses }\end{array}$ & $\begin{array}{c}\text { No. of } \\
\text { dead } \\
\text { males }\end{array}$ & \% of death \\
\hline $\begin{array}{l}\text { Pheromonal coated } \\
\text { decoys }\end{array}$ & $51 / 90$ & $56.66 \%$ & $25 / 30$ & $83.33 \%$ \\
\hline Non coated decoys & $0 / 30$ & $0 \%$ & 0 & $0 \%$ \\
\hline
\end{tabular}

Table (4): Results of testing of tick decoys for B.annulatus naturally infesting cattle

\begin{tabular}{|c|c|c|c|c|c|c|c|c|c|c|c|c|c|c|c|c|}
\hline \multirow[t]{3}{*}{ *Observations } & \multicolumn{16}{|c|}{ ANIMALS } \\
\hline & \multicolumn{10}{|c|}{ Experimental group } & \multicolumn{6}{|c|}{ Control group } \\
\hline & \multicolumn{2}{|c|}{1} & \multicolumn{2}{|c|}{2} & \multicolumn{2}{|c|}{3} & \multicolumn{2}{|c|}{4} & \multicolumn{2}{|c|}{5} & \multicolumn{2}{|c|}{6} & \multicolumn{2}{|c|}{7} & \multicolumn{2}{|c|}{8} \\
\hline \multirow[b]{2}{*}{$\begin{array}{l}\text { No. of males } \\
\text { mounting decoys }\end{array}$} & No & $\%$ & No & $\%$ & No & $\%$ & No & $\%$ & No & $\%$ & No & $\%$ & No & $\%$ & No & $\%$ \\
\hline & 17 & 68 & 13 & 52 & 11 & 44 & 14 & 56 & 15 & 60 & - & & - & & - & \\
\hline Dropped dead ${ }^{\hat{\sigma}} \hat{\sigma}$ & 3 & 12 & 5 & 20 & 3 & 12 & 4 & 16 & 5 & \begin{tabular}{|l|l}
20 \\
\end{tabular} & - & & & & & \\
\hline $\begin{array}{l}* * \text { Dropped } \\
\text { live }{ }^{\lambda} \sigma^{\lambda}\end{array}$ & 8 & 32 & 7 & 28 & 6 & 24 & 8 & 32 & 11 & 44 & - & & & & & \\
\hline Attached dead $\widehat{ }{ }^{\wedge}{ }^{\wedge}$ & 2 & 8 & 1 & 4 & 3 & 12 & 2 & 8 & 3 & 12 & & & & & & \\
\hline Attached live $\sigma^{\wedge} \sigma^{\wedge}$ & 9 & 36 & 11 & 44 & 12 & 48 & 10 & 40 & 10 & 40 & 25 & 100 & 25 & 100 & 25 & 100 \\
\hline Total dead males & 15 & 60 & 13 & 52 & 12 & 48 & 15 & 60 & 19 & \begin{tabular}{|l|l}
76 \\
\end{tabular} & - & & & & & \\
\hline $\begin{array}{l}\text { No of mated } \\
\text { engorged female }\end{array}$ & 8 & 32 & 12 & 48 & 7 & 28 & 9 & 36 & 6 & 24 & 14 & 56 & 17 & 68 & 18 & 72 \\
\hline $\begin{array}{l}\text { No of decoys still } \\
\text { on animal }\end{array}$ & 42 & 84 & 38 & 76 & 33 & 66 & 39 & 78 & 40 & 80 & - & & - & & - & \\
\hline $\begin{array}{lr}\text { No of } & \text { decoys } \\
\text { dropped } & \text { on } \\
\text { ground } & \end{array}$ & 8 & 16 & 12 & 24 & 17 & 34 & 11 & 22 & 10 & 20 & - & & - & & - & \\
\hline
\end{tabular}

* The observations period was ten days from the beginning of the experiment

** All dropped males were died after 1-5 days post-incubation 
Table (5): Biological periods of Boophilus annulatus females in experimental and control groups

\begin{tabular}{|c|c|c|c|c|c|}
\hline $\begin{array}{l}\text { Biological } \\
\text { periods (in } \\
\text { days) }\end{array}$ & $\begin{array}{c}\text { Preoviposition } \\
\text { Mean } \pm \text { SE }\end{array}$ & $\begin{array}{l}\text { Oviposition } \\
\text { Mean } \pm \text { SE }\end{array}$ & $\begin{array}{c}\text { Pre-hatching } \\
\text { Mean } \pm \text { SE }\end{array}$ & $\begin{array}{c}\text { Hatching } \\
\text { Mean } \pm \text { SE }\end{array}$ & $\begin{array}{c}\text { Hatching \% } \\
\text { Mean } \pm \text { SE }\end{array}$ \\
\hline $\begin{array}{l}\text { Experimental } \\
\text { group }\end{array}$ & $\begin{array}{c}4-8 \\
5.88( \pm 1.41)\end{array}$ & $\begin{array}{c}5-6 \\
5.45( \pm 0.5)\end{array}$ & $\begin{array}{c}21-24 \\
22.73( \pm 0.91)\end{array}$ & $\begin{array}{c}12-15 \\
13.38( \pm 0.98)\end{array}$ & $\begin{array}{c}0-25 \\
(13 \pm 1.07)\end{array}$ \\
\hline $\begin{array}{l}\text { Control } \\
\text { group }\end{array}$ & $\begin{array}{c}3-4 \\
3.65( \pm 0.48) \\
\end{array}$ & 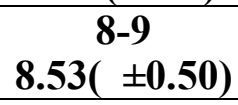 & $\begin{array}{c}17-21 \\
19.67( \pm 1.16)\end{array}$ & $\begin{array}{c}7-10 \\
8.4( \pm 0.99)\end{array}$ & $\begin{array}{c}70-100 \\
82.18( \pm 1.68) \\
\end{array}$ \\
\hline
\end{tabular}

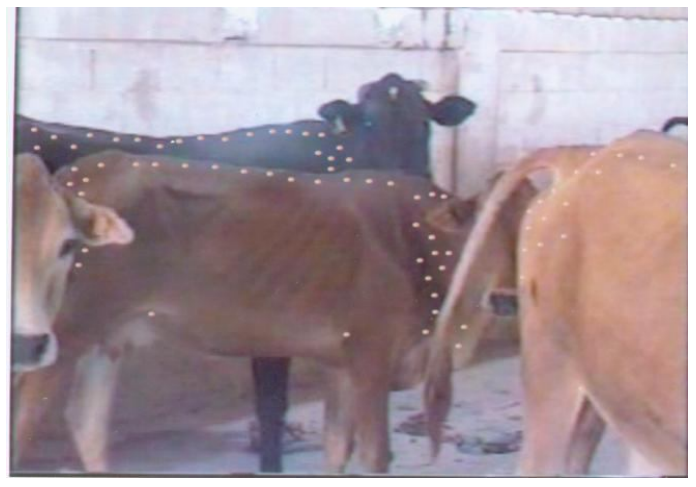

(photo 1) : Distribution of tick decoys on the body of experimental cows.

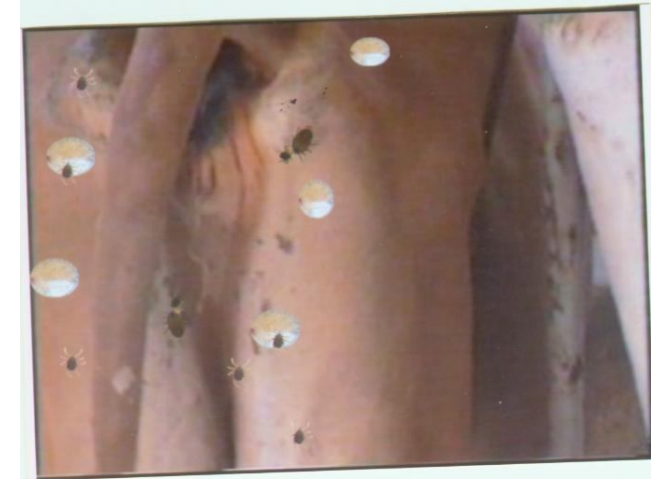

(photo 2 ) Attraction and mounting of male tick to pheromone impregnated tick decoys and natural females

\section{DISCUSSION}

Pheromones are compounds released by individuals of tick species which regulate the behavior of others of that same species (Karlson and Luscher, 1959). Methods of biotechnology and recent advances in instrumentation have enabled us to begin to investigate the pheromones of $B$. annulatus and enabled us to prepare it synthetically to be used in combination with effective acaricides in the form of what is called decoy trying to control the tick.

Thin layer chromatography using (HP) precoated silica gel and petroleum ether, diethyl ether and acetic acid solvents according to the systems of Mangold (1969) and Skipsi et al (1965) was used for the qualitative analysis of the $B$. annulatus pheromone and the results revealed that the pheromone contains cholesterol and 8 cholesteryl esters in addition to 7 triglycerides together with 3 fatty acids. Some standard triglycerides and fatty acids did not develop at all, and this agrees with Mangold (1969) who mentioned that the system does not separate all commonly occurring neutral lipids in biological materials. Several authors used the same technique for analysis of 
biological compound for lipid material among them: Scott (1969) recognized glycerides, phospholipids, cholesterol and cholesteryle esters, Fried and Pucci (1976)who perfonned various analytical TLC studies on arthropods and flatworms and had detected mainly triglycerides, free sterols, and phospholipids. Also Sobbhy et al (1994) applied thin layer chromatography (TLC) on extract of $H$. drornedaril and Rhipicephalus sanguineus ticks and found that cholesterol and cholesteryl esters were the most abundant neutral lipids found on the body surfaces of fed females of these two species.

High pressure liquid chromatography (HPLC) is used for the analysis of the B.annu/atus pheromone and its comparison with the different standards (cholesteryl esters, triglycerides and fatty acids) using Waters Millennium HPLC system with isopropyl alcohol and acetonitrile solvent at a flow rate of $120: 80$ respectively. The matching was based on measuring the retention time (from the beginning of the run till the mid base of the peak) and maximum wave length of peak of tick extract and those of the standards. The results, which done for the first time on Boophilus annulatus ticks in Egypt, revealed that $B$. annulatus pheromone composed of cholesterol $(12.2 \mu \mathrm{g}), 2,6-\mathrm{DCP}(\quad 1 \mu \mathrm{g})$, cholesteryl oleate $(4.6 \mu \mathrm{g})$, cholesteryl hexanoate( $10.1 \mu \mathrm{g})$, cholesteryl linolenate $(8.1 \mu \mathrm{g})$, cholesteryl butyrate $(9.2 \mu \mathrm{g})$, cholesteryl palmitate $(5.6 \mu \mathrm{g})$, cholesteryl linoleate $(3.8$ $\mu \mathrm{g})$, cholesteryl myristate $(4.9 \mu \mathrm{g})$, cholesteryl stearate $(4.7 \mu \mathrm{g})$, cholesteryl laurate $(1.2 \mu \mathrm{g})$ and trilaurin $(121.4 \mu \mathrm{g})$, tn caprin (20.3), trielaidin (17.4 $\mu \mathrm{g})$, tripalmitin $(20.6 \mu \mathrm{g})$, tristearin $(22.1 \mu \mathrm{g})$, tricaproin $(15.9 \mu \mathrm{g})$, trilinolein $(67.8 \mu \mathrm{g})$, tricaprylin $(60.2 \mu \mathrm{g})$, tripalmitolein (143.6), tri-11ecosenoin (117.4) and stearic acid $(8.4 \mu \mathrm{g})$, oleic acid $(5.8 \mu \mathrm{g})$, palmitic acid $(4.3 \mu \mathrm{g})$, arachidonic acid $(1.7 \mu \mathrm{g})$, arachidic acid $(4.9 \mu \mathrm{g})$, linoleic acid $(22.5 \mu \mathrm{g})$, linolenic acid $912.8 \mu \mathrm{g})$ and lauric acid $(14.1 \mu \mathrm{g})$.

Studies on tick pheromones especially those involving sex attractants of more or less similar chemical structure is promising. These studies provide an essential theoretical base of knowledge that may lead to practical application in controlling ticks of medical and veterinary importance.

To the best of our knowledge, there are no data regarding sex pheromone released by $\boldsymbol{B}$. annulatus ticks. Female produced pheromones have been reported in at least four genera of Ixodidae, the first conclusive proof of a pheromone in ticks was presented by (Berger, 1972) who detected 2,6-dichiorophenol from feeding Amblyomma americanum females. A sex attractant pheromone 2,6- DCP which stimulates localized attraction of males to females has been identified in a wide variety of ticks (Sonenshine, 1985). However, sex pheromones released by feeding females of ixodidae ticks stimulate feeding males to detach. These pheromones provide directional information for orienting to recognizing and copulating with the emitting female (Berger, 1972; Kellum and Berger, 1977). Leahy et al. 
(1981) demonstrated the presence of two female pheromones in the metastriate tick Hyalomma dromedarii. These two pheromones were attractant sex pheromone and mounting sex pheromone (MSP). Later on, (Sobbhy et al. 1994) were able to extract and identify the mounting sex pheromone of $H$. drornedarii to be a mixture of six different cholesteryl esters.

The results of our bioassays clearly indicate the presence of a cuticular sex pheromone, the mounting sex pheromone (MSP), produced by $B$. annulatus (Table 3). Following their attraction by 2,6-DCP, males encountering this pheromone mount the females and apply their legs and mouth parts against the female body surface so that the male body is in direct contact with the female. Then, while still in close contact, they move to the female's venter and probe. Thus, this sex pheromone mediates the mounting phase of $B$. annulatus courtship behaviour, as described by Sonenshine (1985) on ixodid ticks. Our findings showed that this cuticular sex pheromone is essential for recognition of the females as a potential mating partner. Males are unable to recognize females lacking this cuticular pheromone as potential mates, and these males terminate their courtship activities.

However, the male responses were restored by depositing the extract onto the bodies of surface-delipidized females or even transferred onto inanimate objects (dummy ticks), evidence which supports the hypothesis that this represents pheromone-mediated behavior.

Attractant decoy technology has many advantages over conventional methods for tick control as spraying, dipping or pour-ons. Firstly, we use only very tiny amount of the acaricides when compared with other methods. So, we can avoid or minimize the pollution of the environment with these toxic chemicals as well as this was beneficial from economic view. Also the toxicity which resulted from using these acaricides due to cumulative effect of their residues in the blood and tissues of animals and human can be reduced. Moreover, the decoys were easy to manufacture and require no specific training for application, making it farmer-friendly technology.

The attractant decoy technology was applied in Egypt for the first time on experimentally infested rabbits by Fahmy and Aggour (1995) or on naturally infested camels with tick by Aggour and Abd El-Gawad (1995) where the pheromone / cyfluthrin impregnated, decoys gave a good results, A high percentage of Hyalomma dromedarii males ranged from 48 - $76 \%$ were attracted by these decoys. Also, most of these males died and the mortality rate reached $72 \%$. Also engorged females either gave infertile eggs or laid very small egg mass with very low hatching percentage. This probably is due to killing of most males so that females could not be inseminated or even mounted. 
Our results showed that using of acaricide impregnated decoys stimulates the male responses towards the decoy by $56.66 \%$ and the eradication of ticks was achieved successfully with $83.33 \%$ tick mortality (Table 3).

The attractant decoy technology was applied on naturally infested cattle with B.annulatus. These decoys gave good results as attracted high percentage of males ranged from $44-60 \%$ with mortality percentage among these males reached $76 \%$. The engorged females collected from treated cattle with decoys either gave unfertile eggs or laid very small egg mass with very law hatching percentage $0-25(13 \pm 1.07)$. This referred to killing of most males, so that females could not be inseminated .

From the aforementioned results, it was clear that application plastic attractant decoys for controlling of B.annulatus in Egypt will be effective.

Acknowledgment: This work has been done through the Egyptian Finish Agriculture Research Project (EFARP). We wish to thank Prof. Dr. Hosni El-Sawah, Animal Health Research Institute and Prof. Dr. Salwa Dogheim, Central Lab. of Residue Analysis of Pesticides \& Heavy metals in food for supplying facilities to carry this work.

\section{REFERENCES}

Aggour, M. G. and Abd El-Gawad, A.F. (1995): Application of tick decoys technology to control, of Hyalomma dromedarii (Acarina: lxodidae) in Egypt. Annals of Agric. Sci., Moshtohor, 33 (2): 875 882.

Berger, R.S. (1972): 2,6-dichlorophenol, sex pheromone of the lone star tick. Science, 177: $704-05$

Fahmy, M.M. and Aggour, M.G. (1995):Experimental trial for testing of pheromone coated tick decoys against Hyalomma dromedarii. Beni-Suef Vet. Med. J,31(3): 323-336

Fried, B. and Pucci, D.L. (1976): Histochemical and thin layer Chromatographic analysis of neutral lipids in Leucochloridiornorpha constanhia (Trematoda) adults. J. Parasitol., 6: $479-482$.

Fried, B. and Sharma, J. (1982): "Thin - Layer Chromatography". Techniques and Application.Chromatographic Science series.Vol 17. MarcelDekker,INC.NewYork and Base2.Ame.67:750-752.

Gladny,W.J.;Ernst,S.E.and Grabbe,R.R.(1974): The Aggrgation response of the Gulf Coast ticks on cattle. Ann. Entomol. Soc. Amer., 76:750-752 
Hamilton, J.G.; Papadopoulos, E.; Harrison, S.J.; Lloyd, CM. and Walker, A.R. (1994): Evidence for a mounting sex pheromone in the brown ear tick Rhipicephalus appendiculatus ${ }_{2}$ Neuman $_{1901}$ (Acari: Ixodidae). Exp. Appl. Acarol., 18 (6): 331-338.

Hamilton, G.C and Sonenshine, D.E. (1988): Evidence for occurrence of mounting sex pheromone on body surface of female Dermacentor variabilis (Say) and Dermacentor andersoni (Stiles) (Acari: Ixodidae). J .Chem. Ecol. ,14 (1): 401 - 410.

Hess, $E$ and De-Castro-JJ (1986) : Field tests of the response of female Amblyomma variegaturn (Acari:Ixodidae) to the synthetic aggregation-attachment pheromone and its components. Exp-App.Acarol. 2 (3): 249-55.

Hoogstraal, H. (1956): African Ixodidae. Ticks of the Sudan. (with special reference to equatorial province and with preliminary reviews of the genera Boophilus, Margaropus, and Hyalomma). Vol. I. Research report NM 005 050. 29.07.

Karlson, P. and Luscher, M. (1959): "Pheromones": a new term for a class of biologically active substances. Nature London,183:55- 56.

Kellum, D. and Berger, R.S. (1977): Relationship of the occurrence and function of 2,6-dichiorophenol in two species of Amblyomma (Acari: Ixodidae). J. Med. Entomol., 13: $701-705$.

Leahy, M. G.; Hajkova, Z. and Bouchalova, J. (1981): Two female Pheromones in the metastriate tick Hyalomma dromedarii (Acarina, Ixodidae). Acta. Ent. Bohemosv. ,78: $224-30$.

Lusby, WR., Sonenshine, D.E.; Yunkèr, CE.; Norval, R.A.; Burridge,M.J. (1991): Comparison of known and suspected pheromonal constituents in males of African ticks, Amblyomma hebraeum Koch and Amblyomma vanegatum_(Fabricius). Exp. Appl. Acarol., 13 (2): 143-52.

Mangold, H.K. (1969): Aliphatic lipids. In Thin Layer Chromatography 2ed E. Stahl (Ed.). Springer - Verlag, New York, pp. 363 - 421.

Norval, R.A.; Andrew, H.R. and Meltzer, M.I. (1991 a): Seasonal occurrence of the bont tick (Amblyomma hebraeum) in the southern lowveld of Zimbabwe. Exp. Appi. Acarol., 13(2): 81-96

Norval, R.A.; Yunker, CE.; Duncan, LM. and Peter, (199l b): Pheromone/acaricide mixtures in the control of the tick Amblyomma hebraeum: effects of acaricides on attraction and attachment. Exp. Appl. Acarol. 11(2-3): 233-40.

Ristic, M. (1988): Babesiosis. University of Illinois, Urbana, Ill. Illustrated Manual for the Recognition and Diagnosis of Certain Animal Diseases.2: 5-9.

Scott, R.M. (1969): Clinical analysis by thin layer chromatography techniques. Ann Arbor Science Publishers, Michigan. 
Skipski, V.P. Smolowe, A.F.; Sullivan, R.C. and Barclay, M. (1965): Separation of lipid classes by thin-layer chromatography. Biochem. Biophys. Acta., 106: 386 - 396.

Sobbhy, H.; Aggour, M. G.; Sonenshine, D. E.; Burridge, M. J. (1994): Cholesteryl esters on the body surfaces of the camel tick, Hyalomma dromedarii_and the brown dog tick, Rhipicephalus sanguineus. Exp. Appl. Acarol., 18 (5): 265-280.

Sonenshine, D.E. (1985): Pheromones and other semichemicals of the Acari. Annu. Rev. Entomol. 30: 1-28

Yunker, CE.; Peter, T.; Norval, R.A.; Sonenshine, D. E. Burridge, M. J. and Butler-JF (1992): Olfactory responses of adult Amblyomma hebraeum and $A$ variegatum_(Acari: Ixodidae) to attractant chemicals in laboratory tests. Exp. Appl. Acarol., 13 (4): 295-301

Ziv, M.; Sonenshine, D. E.; Silverstein, R.M.; West. 1. R. and Gingher, KH. (1981): Use of sex pheromone, 2,6 - dichiorophenol, to disrupt mating by American dog tick, Dermacentor variabilis (Say). Chem. Ecol., 7: 829 40. 


\title{
الملخص العربى
}

\section{التطبيق الحقلى لتقتية مصائد القراد المغطاة بالفيروفون}

\author{
كوسيلة لمقاومة قراد البووفيلس انيولاتس
}

$$
\begin{aligned}
& \text { أ.د/ محمد جلال عجور د. خالا عبد الحكيم مهران } \\
& \text { معهد بحوث صحة الحيوان - قسم بحوث البيوتكنولوجي }
\end{aligned}
$$

فى هذا البحث تم استخدام تقنية "مصائد القراد" فى مقاومة قراد الأبقار نوع "بووفيلس انيولاتس" حيث تـم التعـرف وتحليـل الفيرمونـات (الجاذبـات الجنسية) المستخلصة مـن انـاث القـراد باسـتخدام طـرق التحليل الكرومـاتوجرافى (الالواح الرقيقة وجهاز الكرومـاتوجرافى ذو الضغط العـالى) ووجد استجابة عالية فى اجتذاب ذكور هذا القراد نحو الفيرمون المحضر للاناث وصلت الى 77 7ه\% ووصلت نسبة موت ذكور القراد عند استخدام هذه المصائد البلاستيكية المغطاة بالقرمونات الى سبو سر\% وقد أجريت تجربة حقلية لمعرفة كفاءة هذه المصائد المغطاة بفيرمونات هذا النوع من القراد (محتوية

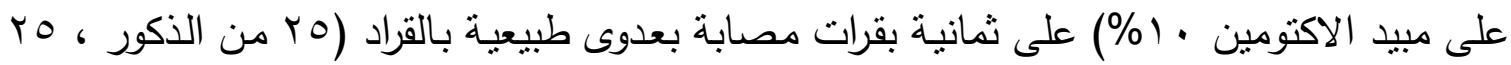
من الاناث على كل حيوان) وقد تم تقسيم هذه الأبقار الى مجموعتين ، مجموعة مكونة من خمس بقرات (وضع على كل منها ـ كبسولة بلاستيكية) بالاضافة الى مجموعة ضـابطة مكونة من ثلاث بقرات.وبعد وضـع الكبسولات البلاستيكية لوحظ انجذاب معظم ذكور هذا القراد نحوها مما أدى الى موتها(\%VT\% نتيجة لاختلاطها بالمبيد. اما بالنسبة لاناث هذا القراد فتم حفظها فى حضانة بيولوجية حيث وضعت بيضا غير مخصب. 